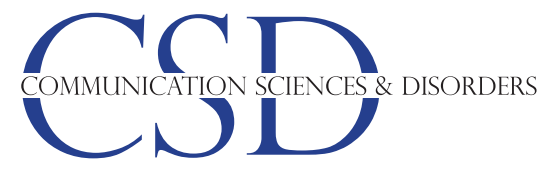

Erratum

| ISSN 2288-0917 (Online) | Commun Sci Disord 2019;24(1):261

\title{
Correction: Content Validity of the Swallowing Monitoring and Assessment Protocol for the Elderly
}

\author{
HyangHee Kim, ${ }^{\mathrm{a}, \mathrm{b}}$, Ga-Young Kimª, Hyun-Joung Lee
}

https://doi.org/10.12963/csd.18544

Commun Sci Disord 2018;23(4):1042-1054

The title of Table 7 overlaps another table in this article. The correct title of Table 7 is below:

Table 7. CVI of clinical swallowing assessment items

Also, the Acknowledgments section of the above article incorrectly described. The correct statement should read:

This research was supported by the National Research Foundation of Korea (NRF) Grant funded by the Ministry of Science and ICT for convergent research in development program for convergence R\&D over Science and Technology Liberal Arts (No. NRF-2017M3C1B6070665).

이 논문은 2017년도 정부(과학기술정보통신부)의 재원으로 한국연구재단-과학기술인문사회융합연구사업의 지원을 받아 수행된 연구 임(No. NRF-2017M3C1B6070665). 